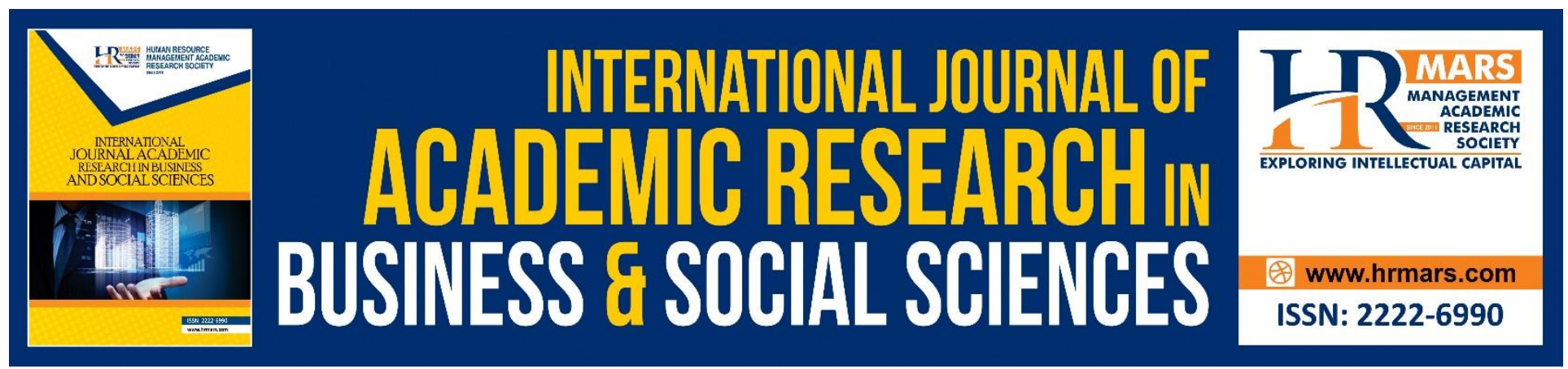

\title{
Measuring the Financial and Nonfinancial Performance of Micro-Enterprise in Pahang, Malaysia
}

\author{
Nurul Nadiah Ahmad \& Nurul Nazlia Jamil
}

To Link this Article: http://dx.doi.org/10.6007/IJARBSS/v10-i10/8004

DOI:10.6007/IJARBSS/v10-i10/8004

Received: 02 August 2020, Revised: 27 August 2020, Accepted: 17 September 2020

Published Online: 20 October 2020

In-Text Citation: (Ahmad, \& Jamil, 2020)

To Cite this Article: Ahmad, N. N., \& Jamil, N. N. (2020). Measuring the Financial and Nonfinancial Performance of Micro-Enterprise in Pahang, Malaysia. International Journal of Academic Research in Business and Social Sciences. 10(10), 706-717.

Copyright: (C) 2020 The Author(s)

Published by Human Resource Management Academic Research Society (www.hrmars.com)

This article is published under the Creative Commons Attribution (CC BY 4.0) license. Anyone may reproduce, distribute, translate and create derivative works of this article (for both commercial and non-commercial purposes), subject to full attribution to the original publication and authors. The full terms of this license may be seen at: $\underline{\text { http://creativecommons.org/licences/by/4.0/legalcode }}$

Vol. 10, No. 10, 2020, Pg. 706 - 717

http://hrmars.com/index.php/pages/detail/IJARBSS

JOURNAL HOMEPAGE

Full Terms \& Conditions of access and use can be found at http://hrmars.com/index.php/pages/detail/publication-ethics 


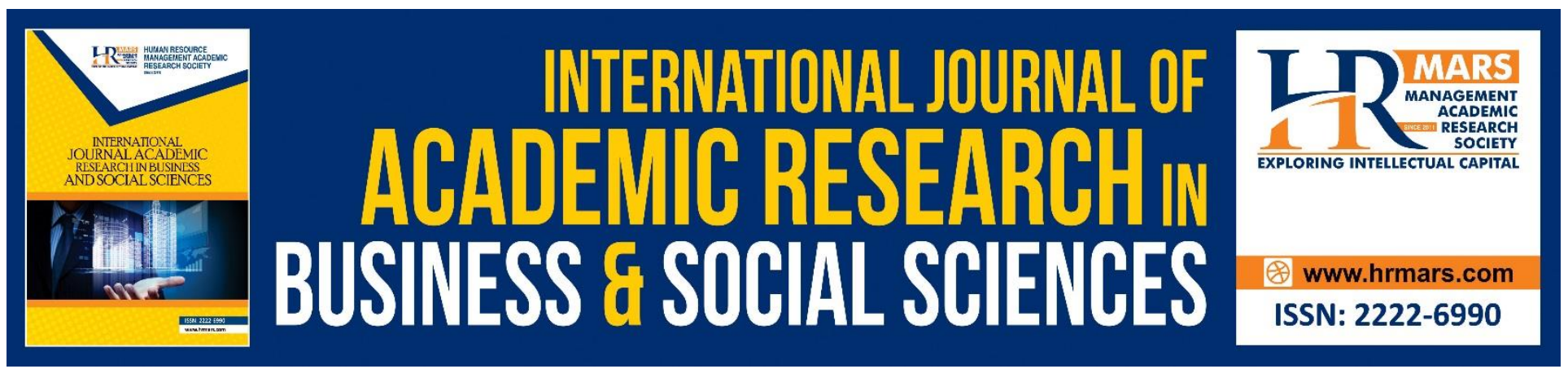

\title{
Measuring the Financial and Nonfinancial Performance of Micro-Enterprise in Pahang, Malaysia
}

\author{
Nurul Nadiah Ahmad ${ }^{1} \&$ Nurul Nazlia Jamil ${ }^{2}$ \\ ${ }^{1}$ College of Business Management and Accounting, Universiti Tenaga Nasional, Sultan Haji Ahmad \\ Shah Campus, Malaysia, ${ }^{2}$ Faculty of Economics and Muamalat, Universiti Sains Islam Malaysia \\ (USIM), Malaysia.
}

\begin{abstract}
Malaysian economic growth is greatly contributed by the micro-enterprises as the highest establishments among Small and Medium Enterprises (SMEs). However, the performances of microenterprises are not as good as expected. Most of them cannot survive and sustain the enterprises for an extended period, and some have faced bankruptcy. Thus, this study aims to examine their performance in terms of financial and nonfinancial aspects. Financial performance is based on estimated profits, sales and cash flow, while nonfinancial performance is measured by using employee conditions, valued customer, and product development. A total of 200 sets of the questionnaire were distributed to micro-enterprises in Pahang, Malaysia. The result of this study shows that most of the selected micro-enterprises have good financial and nonfinancial performance, but they perform better in term of nonfinancial rather than the financial aspect. This study is valuable for practitioners such as owners/managers, which will help them to make a better strategy to have an improvement in the financial aspect.
\end{abstract}

Keywords: SME, Micro-Enterprises, Financial Performance, Nonfinancial Performance, Malaysia.

\section{Introduction}

SMEs play a vital role in the economic growth of the world by providing a high quality of products/services in order to compete in a competitive environment. In addition, SMEs also offer the opportunity for job improvement in order to enhance their efficiency and effectiveness (Farhan \& Nur Naha, 2011). Besides, Nurazree and Faiz (2013) stated that SMEs have become a backbone in the economic development of most countries, including both developed and developing countries.

Some of the SME are facing troubles and difficulties, especially in surviving and sustaining the enterprise in a competitive environment (Nyanga, Zirima, Mupani, Chifamba \& Mashavira, 2013). According to Wong, Kuek, and Ong (2013), most of the SMEs could not sustain themselves over the long-term period due to poor performance. In addition, some SMEs could not survive the first five years of their establishments in the market due to failure in planning excellent strategies in order to sustain the enterprise (Monge-Gonzalez \& Torres-Carballo, 2015). Moreover, Mbugua, Agnes and 
INTERNATIONAL JOURNAL OF ACADEMIC RESEARCH IN BUSINESS AND SOCIAL SCIENCES Vol. 10, No. 10, 2020, E-ISSN: 2222-6990 @ 2020 HRMARS

Ondabu (2014) explained that SMEs performed poorly, added with poor management that has directly caused the enterprises failed to grow. SMEs are facing high competition not only from their peers but also from large corporations (Mbugua et al., 2014; Awa, Ojiabo \& Emecheta, 2012). Besides, SMEs, especially micro-enterprises frequently struggle with higher tensions because of the strong micro influence within their operating foundation (Cheing, Hong, Kuek, Chai, \& Cham, 2020).

Many new enterprises were established in Malaysia are selling commodity products which are similar products within the market. This situation has led them to fail to sustain or enlarge their enterprises. Apart from that, SMEs are usually being despised by the customers for the products/services provided by them. The customers pointed that the products/services provided are lack of quality and could not meet their demands, although, they have not even tried the products/services yet (Mbugua et al., 2014). Besides, The Edge (2019) discussed that micro-enterprises are in low-productivity economic activities because both are difficult for the business owners and employees to increase their earning power.

Compared to large or medium enterprises, microenterprises have distinctive features such as limited financial, human and technological abilities, and formation of the primary source of income for their owners and employees (Fazal, Al Mamun, Mansori, \& Abir, 2019). Therefore, this study aims:

- to examine the performance of micro-enterprises in Malaysia in terms of financial and nonfinancial performance.

\section{Literature Review}

\section{Micro-enterprise in Malaysia}

Based on Figure 1, SMEs had been classified into three categories (micro, small, and medium enterprises) based on a number of the labour force, size of the company, income level, and capital requirement (Khrystyna, Melina \& Rita, 2010).

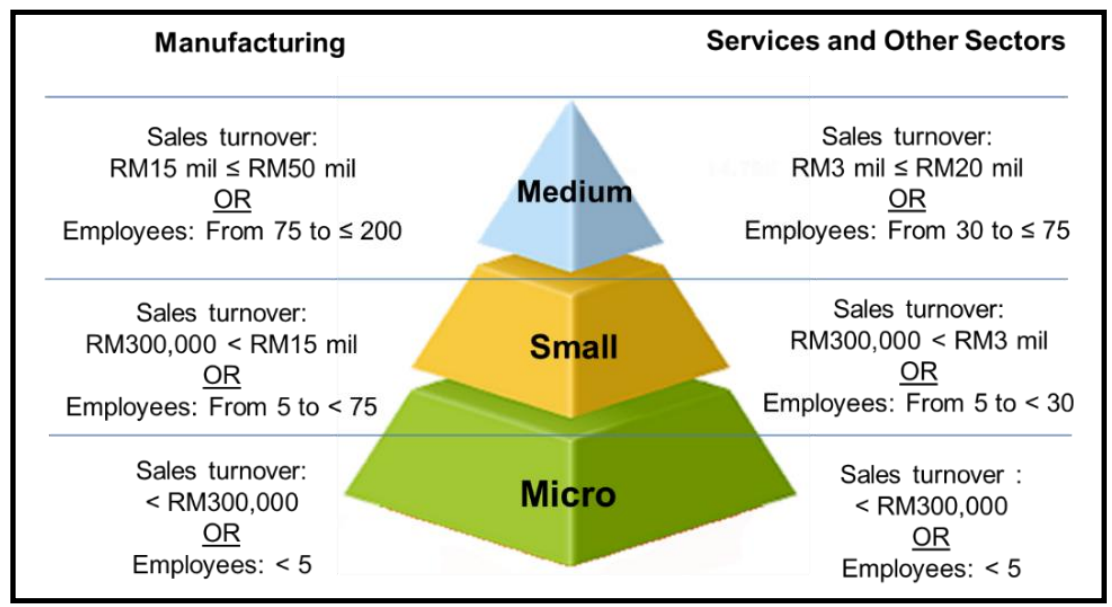

Figure 1: SMEs definition

Source: SME Corp. Malaysia, 2018 
INTERNATIONAL JOURNAL OF ACADEMIC RESEARCH IN BUSINESS AND SOCIAL SCIENCES Vol. 10, No. 10, 2020, E-ISSN: 2222-6990 @ 2020 HRMARS

Figure 2 shows the number of SMEs establishments in the year 2018, where the majority of the establishment came from the micro-enterprises (76.5\%). Whereas, the number of establishments for small and medium enterprises is $21.2 \%$ and $2.3 \%$ of total SMEs respectively.

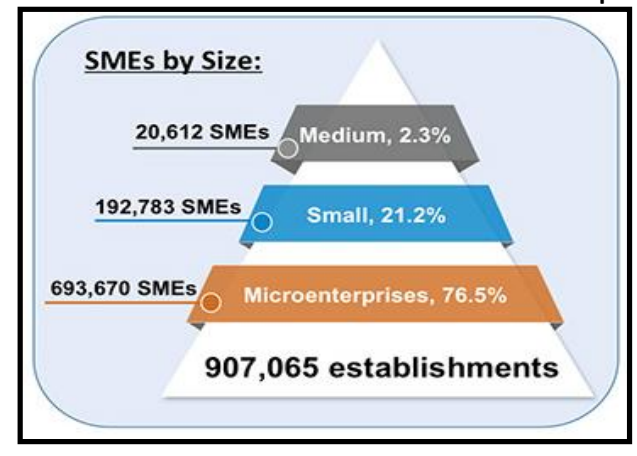

Figure 2: SMEs establishment Source: SME Corp. Malaysia, 2018

\section{Performance of SMEs}

In arrears to globalisation, SMEs are forced to embrace competitive strategies in order to be relevant in the environment. According to the Capital Markets Authority (2010), in this world, more than $99 \%$ of enterprises formed are SMEs. In addition, SMEs account for the huge shares of the private enterprise is complex virtually in all economies of the countries, and over $60 \%$ of the global informal and formal workforce is employed by SMEs (The World SME Forum, 2015). In 2014, the share of SMEs in the total enterprise's population ranged around $99.5 \%$ to more than $99.9 \%$ in European countries. Furthermore, SMEs in the nonfinancial enterprise sector employed almost 90 million people which equals to 67\% of the sector's total employment in Europe for 2014 (European Commission, 2015). On the other hand, Khrystyna, Melina, and Rita (2010) clarified that from 2000 to 2009, the number of SMEs that has been established based on 1,000 people grew by $6 \%$ per year globally. The highest increase rate with $15 \%$ growth is in Europe and Central Asia.

Some of SMEs faced troubles and a lot of problems in surviving their enterprises in the market. Previous studies found that most of these SMEs around the world failed to continue or expand their enterprises within the first five years in the market. They were usually operated for less than five years and then got closed down (Wong et al., 2013; Noor Hazlina \& Pi-shen, 2009). Meanwhile, approximately $60 \%$ of SMEs in Malaysia failed to sustain in the business (Nurulhasanah, Zulnaidi, \& Rafisah, 2014). Abu, Rohani, Subarna, and Azrai (2011) added that this failure was high among new firms, which tend to come from micro-enterprises. Studies also revealed that more than $90 \%$ of new start-up enterprises have failed within five years of their operations. This fact concluded that only $10 \%$ of these new start-up enterprises have survived beyond five years.

Daniel and Okibo (2014) stated that the performance of enterprises can be determined by their competitive strategy, which means the enterprise with a higher competitive advantage compared to its competitor will have better performance and vice versa. Moreover, the efficiency and effectiveness of enterprise strategy implemented will define their performance as well. According to Chong (2008), various theoretical frameworks exist to evaluate the effectiveness and performance of an enterprise which includes competitive value approach, system resource approach, stakeholder approach, and goal approach.

The term "performance" is used in foreign research and academic literature to describe the results of companies' business activities (Kotane \& Kuzmina-Merlino, 2017). Business performance can be 
INTERNATIONAL JOURNAL OF ACADEMIC RESEARCH IN BUSINESS AND SOCIAL SCIENCES Vol. 10, No. 10, 2020, E-ISSN: 2222-6990 @ 2020 HRMARS

measured by a number of actions that can be broadly divided into financial performance and nonfinancial performance. Some other common measures are profitability, productivity, growth, stakeholder satisfaction, market share and competitive position (Bagorogoza \& de Waal, 2010; Garrigós-Simón \& Marqués, 2004). However, financial elements are not the only indicator for measuring firm performance. It needs to be combined with nonfinancial measurement in order to adapt to the changes in internal and external environments (Rosli \& Sidek, 2013). However, in SMEs limitations, the subjective measurements are more valuable than objective measurement due to the lack of availability and reliability of information (Tayeh, Al-Jarrah, \& Tarhini, 2015). Thus, this study used the following measures to measure SMEs performance: financial performance and nonfinancial performance.

\section{Financial Performance}

Annastazia and Robert (2014) defined financial performance as the process synonymous to the interpretation of financial statements of the enterprise. Moreover, Nyangoma (2012) stated that the capability of the enterprise to create wealth during the start-up of the enterprise and survive or maintain in the market show positive financial performance. Generally, financial performance is a subjective measure of how excellent enterprises can utilise their assets from their primary enterprise activities and generate future cash inflow to the entity. The performance reflects an overall enterprise financial situation or condition over a specific period of time and can be used to compare with another enterprise within the same industry in order to evaluate the performance.

There are numerous measurements of financial performance includes profitability, size and growth. While, this study uses (i) profit, (ii) sale and (iii) cash flow to measure the financial performance of micro-enterprises as this study was replicated from previous studies (Mashenene, Macha \& Donge, 2014; Annastazia \& Robert, 2014; Tundui, 2012; Nyangoma, 2012). Tundui (2012) used the sales volume to measure the financial performance of SMEs. As the higher sales volume of the enterprise, it indicates the higher profit that enterprise obtained and thus, the enterprise has a good performance. Sales growth remains an important representation of corporate financial performance, including for SMEs. The ability to access to financial services, especially access to credit at affordable and lower costs will increase the sales growth of the business (Lee, Wang, \& Ho, 2020). Furthermore, the stable profit and growth of the enterprise show that it has a good performance (Annastazia \& Robert, 2014; Nyangoma, 2012). On the other hand, it is easier for the enterprise to get this kind of financial information if the enterprise keeps and maintains the record properly. Besides, good cash flow is essential for every business to increase profitability, sustainability, and future planning (Ahmad, 2016). Cash flow is important in describing the inflow and the outflow of cash, which refers to the movement of cash in the receiving to payment cycle.

\section{Nonfinancial Performance}

Dikolli (2010) defined nonfinancial performance as any measurement of quantitative information about the enterprise that is not stated in a monetary unit. Instead of accessing quantitative information in monetary value, enterprises need to evaluate qualitative evidence as well, in order to justify whether their performance is satisfied or not. Recently, many enterprises have seen qualitative information as a vital part of improving their performance. Therefore, nonfinancial performance measures are expected to be the leading indicators of future performance measurement. Common 
INTERNATIONAL JOURNAL OF ACADEMIC RESEARCH IN BUSINESS AND SOCIAL SCIENCES Vol. 10, No. 10, 2020, E-ISSN: 2222-6990 @ 2020 HRMARS

examples of nonfinancial performance include measures of employee or customer satisfaction, market expansion or growth and the number of new products produced.

Measurement for the nonfinancial performance of micro-enterprises in term of their valued customer, employee's condition and product development as this study was replicated from previous studies (Daniel \& Okibo, 2014; Christopher \& David, 2003). According to Christopher and David (2003), the nonfinancial performance of the enterprise can be measured by customer loyalty and employee satisfaction that ultimately affect the profitability of the enterprise. As there are more customers and employee's loyalty in the enterprise due to satisfaction with the products/services provided, then the enterprise has a good performance. A business will generate customer satisfaction and a loyal customer when the business is able to take care of customer needs. Meanwhile, Daniel and Okibo (2014) used growth in employees, markets and product development in measuring the nonfinancial performance of the enterprise. If the enterprise attempts to explore a new market or produce new products/services, then it will increase its performance.

\section{Methodology}

An instrument on financial and nonfinancial performance was constructed using a questionnaire to collect the data needed. The unavailability of the annual report and proper financial statements by micro-enterprises has required this development of the questionnaire. This questionnaire was replicated from previous studies of Mamorena and Olumide (2014), Peninnah (2014), Mbugua et al. (2014) and $\mathrm{Wu}$ (2009). The instrument was pre-tested and further refined. The questionnaire was comprised of two sections. The first section is on socio-demographic (4 Questions), and the second section is on financial (9 statements) and nonfinancial (9 statements) performance. The second section uses a 5-point Likert scale from strongly disagree to strongly agree. This questionnaire was distributed and collected by hand to the owner/ manager of micro-enterprises in December 2019. The data collection was done at the four districts in Pahang in the rural area. By employing a simple random sampling, a total of 200 respondents were selected as the respondents. Each of the institutions was represented by 50 respondents. The data gathered were analysed using SPSS.

\section{Result \& Findings}

Table 1 showed the socio-demographic data of the respondents studied. There is a total of 4 statements included in this demographic section covering the highest level of education, business activity, years of enterprise establishment, and sources of initial capital. 
INTERNATIONAL JOURNAL OF ACADEMIC RESEARCH IN BUSINESS AND SOCIAL SCIENCES Vol. 10, No. 10, 2020, E-ISSN: 2222-6990 @ 2020 HRMARS

Table 1: Socio-demographic of respondents $(n=200)$

\begin{tabular}{|c|c|c|}
\hline Socio-demographic & Frequency & Percent \\
\hline \multicolumn{3}{|l|}{ Highest Level of Education } \\
\hline None & 46 & 23.0 \\
\hline Primary school & 18 & 9.0 \\
\hline Secondary school & 91 & 45.5 \\
\hline Diploma & 29 & 14.5 \\
\hline Bachelor's degree & 11 & 5.5 \\
\hline Master's degree & 3 & 1.5 \\
\hline Doctoral degree & 2 & 1.0 \\
\hline \multicolumn{3}{|l|}{ Business Activity } \\
\hline Healthcare/ Beauty care & 26 & 13.0 \\
\hline Transportation & 7 & 3.5 \\
\hline Accommodation & 6 & 3.0 \\
\hline Tuition & 6 & 3.0 \\
\hline Finance & 2 & 1.0 \\
\hline Insurance & 3 & 1.5 \\
\hline Clothing & 25 & 12.5 \\
\hline Sports & 8 & 4.0 \\
\hline Hardware & 16 & 8.0 \\
\hline Gadget & 22 & 11.0 \\
\hline Food and drinking & 60 & 30 \\
\hline Households & 3 & 1.5 \\
\hline Accessories & 7 & 3.5 \\
\hline Retail & 4 & 2.0 \\
\hline Workshop & 5 & 2.5 \\
\hline \multicolumn{3}{|c|}{ Years of Enterprise Establishment } \\
\hline Less than two years & 15 & 7.5 \\
\hline $2-4$ years & 63 & 31.5 \\
\hline $5-7$ years & 59 & 29.5 \\
\hline $8-10$ years & 27 & 13.5 \\
\hline More than 10 years & 36 & 18.0 \\
\hline \multicolumn{3}{|l|}{ Sources of Initial Capital } \\
\hline Personal saving & 132 & 66.0 \\
\hline Bank loan & 30 & 15.0 \\
\hline MARA & 11 & 5.5 \\
\hline MIDA & 1 & 0.5 \\
\hline TEKUN & 4 & 2.0 \\
\hline Amanah Ikhtiar & 16 & 8.0 \\
\hline SME Corporation & 6 & 3.0 \\
\hline
\end{tabular}

Table 2 represents the result of a descriptive analysis of financial performance. The result shows that the mean values for all variables of financial performance which are more than 3 (neither disagree 
INTERNATIONAL JOURNAL OF ACADEMIC RESEARCH IN BUSINESS AND SOCIAL SCIENCES Vol. 10, No. 10, 2020, E-ISSN: 2222-6990 @ 2020 HRMARS

nor agree). The item Sales has the highest mean value of 3.53 (agree) as the range values between 1.33 (strongly disagree) and 5 (strongly agree). The rank is followed by item Profit with the mean value of 3.52 (agree) as the range values 1.33 (strongly disagree) to 5 (strongly agree). Next, the mean value of cash flow is 3.31 (neither disagree nor agree) as the range values of 1 (strongly disagree) to 5 (strongly agree). Therefore, it can be concluded that most of the respondents in Pahang agreed that their micro-enterprises have good financial performance. It might be due to the strategic enterprise location that could attract many customers to buy their products/service and directly lead them to a high sales amount. Subsequently, it contributes to their high profit as well. However, cash flow indicator seems to be low compared to others due to lack of management skill and ability among them in managing their cash in and out (Moya, 2015).

Table 2: Descriptive Statistics Analysis for financial performance

\begin{tabular}{lccccc}
\hline & $\boldsymbol{N}$ & Min & Max & Mean & Std. Dev. \\
\hline MFPP & 200 & 1.33 & 5.00 & 3.52 & 0.77 \\
MFPS & 200 & 1.33 & 5.00 & 3.53 & 0.79 \\
MFPC & 200 & 1.00 & 5.00 & 3.31 & 0.74
\end{tabular}

Where: MFPP=Mean of Financial Performance for Profit, MFPS=Mean of Financial Performance for Sales, MFPC=Mean of Financial Performance for Cashflow

A total of nine statements have been utilised to get a measurement regarding the financial performance of micro-enterprise in Pahang. Based on data shown in Table 3, three highest mean scores are recorded by the statement of "This enterprise makes a profit for this year" $(\mathrm{M}=3.60)$, and "This enterprise makes higher sales for this year" $(\mathrm{M}=3.60)$ followed by "Profit for this year is higher than last year" ( $\mathrm{M}=3.56)$.

Table 3: Statements measuring financial performance

\begin{tabular}{|c|c|c|}
\hline $\begin{array}{l}\text { Variable } \\
\text { s }\end{array}$ & Statements & $\begin{array}{l}\text { Mean } \\
\text { score }\end{array}$ \\
\hline \multirow[t]{3}{*}{ Profit } & This enterprise makes a profit for this year. & 3.60 \\
\hline & Profit for this month is higher than last month. & 3.42 \\
\hline & Profit for this year is higher than last year. & 3.56 \\
\hline \multirow[t]{3}{*}{ Sales } & This enterprise makes higher sales for this year. & 3.60 \\
\hline & Sales for this month are higher than the last month. & 3.49 \\
\hline & Sales for this year are higher than the last year. & 3.52 \\
\hline \multirow{3}{*}{$\begin{array}{l}\text { Cash } \\
\text { flow }\end{array}$} & This enterprise makes higher cash flow for this year. & 3.33 \\
\hline & $\begin{array}{l}\text { For this month, the actual cash income higher than the budgeted cash } \\
\text { income. }\end{array}$ & 3.32 \\
\hline & $\begin{array}{l}\text { For this year, the actual cash income higher than budgeted cash } \\
\text { income. }\end{array}$ & 3.29 \\
\hline & Overall mean for financial performance & 3.46 \\
\hline
\end{tabular}

*Note: 1=Strongly disagree, 2=Disagree, 3= Neither disagree nor agree, 4=Agree \& 5=Strongly agree 
INTERNATIONAL JOURNAL OF ACADEMIC RESEARCH IN BUSINESS AND SOCIAL SCIENCES Vol. 10, No. 10, 2020, E-ISSN: 2222-6990 @ 2020 HRMARS

Table 4 shows that the mean values for overall nonfinancial performance elements are more than 3 (neither disagree nor agree). The item Employees has the highest mean value of 4.11 (agree) as the range values 2 (disagree) to 5 (strongly agree). Meanwhile, both Customer and Product Development have the same mean values of 3.74 (agree) and the maximum score of 5 (strongly agree). However, the minimum score for the Customer is 1 (strongly disagree) and product development is 1.67 (disagree) correspondingly. Therefore, it can be concluded that the majority of respondents in those four states agreed that their enterprises have good nonfinancial performance.

Table 4: Descriptive Statistics Analysis for nonfinancial performance

\begin{tabular}{lccccc}
\hline & $\boldsymbol{N}$ & Min & Max & Mean & Std. Dev. \\
\hline MNPE & 200 & 2.00 & 5.00 & 4.11 & 0.61 \\
MNPC & 200 & 1.00 & 5.00 & 3.74 & 0.71 \\
MNPP & 200 & 1.67 & 5.00 & 3.74 & 0.66 \\
\hline
\end{tabular}

Where: MNPE=Mean of Nonfinancial Performance for Employees, MNPC=Mean of Non-financial Performance for Customer, MNPP=Mean of Non-financial Performance for Product Development

The mean scores of each of the statements were gathered for further analysis. Based on the results gained in Table 5, the statement of "employees have committed to work in the enterprise" recorded the highest mean score $(M=4.13)$. Meanwhile, the statement of "this enterprise always adds more the number of products/ services" ( $M=3.32)$ has the lowest mean score.

Table 5: Statements measuring nonfinancial performance

\begin{tabular}{|l|l|c|}
\hline Variables & Statements & $\begin{array}{c}\text { Mean } \\
\text { score }\end{array}$ \\
\hline \multirow{2}{*}{$\begin{array}{c}\text { Employee } \\
\text { condition }\end{array}$} & This enterprise has an employee skilled and efficient. & 4.09 \\
\cline { 2 - 3 } & Employees have committed to work in the enterprise. & 4.13 \\
\cline { 2 - 3 } $\begin{array}{l}\text { Valued } \\
\text { customer }\end{array}$ & Employees' has satisfied with their work performed. & 4.11 \\
\cline { 2 - 3 } & This enterprise has received many new customers. & 3.68 \\
\cline { 2 - 3 } & The number of customers for this year is higher than last year. & 3.72 \\
\hline \multirow{2}{*}{$\begin{array}{l}\text { Product } \\
\text { development }\end{array}$} & $\begin{array}{l}\text { This enterprise always adds more to the number of products/ } \\
\text { services. }\end{array}$ & 3.32 \\
\cline { 2 - 3 } & $\begin{array}{l}\text { This enterprise is only able to sell good quality of } \\
\text { products/services. }\end{array}$ \\
\cline { 2 - 3 } & $\begin{array}{l}\text { This enterprise adapts to changes in trends and preferences of } \\
\text { customers really well. }\end{array}$ & 3.95 \\
\hline \multicolumn{1}{|c}{ Overall mean for nonfinancial performance } \\
\hline
\end{tabular}

*Note: 1=Strongly disagree, 2=Disagree, 3= Neither disagree nor agree, 4=Agree \& 5=Strongly agree

\section{Conclusion}

The objective of this study is to measure the level of performance of micro-enterprises in Malaysia. It can be measured by the financial and nonfinancial performance of an enterprise. Most of the micro- 
INTERNATIONAL JOURNAL OF ACADEMIC RESEARCH IN BUSINESS AND SOCIAL SCIENCES Vol. 10, No. 10, 2020, E-ISSN: 2222-6990 @ 2020 HRMARS

enterprises in Malaysia have a good financial and nonfinancial performance during their operating period. However, nonfinancial performance has better score compared to financial performance.

This study may be beneficial to micro-entrepreneurs. The manager needs to have the responsibility to balance the enterprise's performance from time to time. For example, the manager needs to improve the product's/service's quality so that the manager and enterprises can get benefits from profit and turnaround capital. Also, by increasing capital indirectly, the revenues and sales of the enterprise will be increased, and it shows that the enterprise' performance has improved.

This study contributes benefits to the practitioners, policy and literature. Firstly, practitioners refer to the owners/managers of SMEs. This study will provide the framework for the owners/managers of the enterprise in determining and monitoring the level of performances, whether financially or nonfinancially for their micro enterprises. Apart from that, policy refers to the principle action proposed by regulators. This study can be beneficial for regulators to enhance the policy in order to improve micro enterprises performance. It may assist the government, financial institutions and other interested parties with SMEs to make policy decisions reliably and can give advantages to SMEs as a whole in the future. Besides, this study can be beneficial for the future researcher because this study is really different from previous studies. For instance, this study focuses on micro enterprises only, while, previous studies focused on SMEs as a whole (Souksavanh, 2014; Wong et al., 2013; Krishna et al., 2012; Che Zuriana \& Rapiah, 2011).

\section{Acknowledgement}

We are thankful to UNITEN for the Internal Research Grant (BOLD2019), which enabled this research to be conducted.

\section{References}

Abu, B. S. A. J., Rohani, S., Subarna, S., \& Azrai, A. (2011). Entrepreneurial Challenges Confronting Micro-enterprise of Malaysian Malays. International Journal of Social, Behavioral, Educational, Economic and Management Engineering, 5(11), 226-231.

Ahmad, N. N. (2016). Cash management practices in micro and small businesses in Malaysia. Journal of Education and Social Sciences, 4, 331-335.

Annastazia, M., \& Robert, G. M. (2014). Socio-Cultural Factors and Financial Performance among Women Small and Medium Enterprises in Tanzania. European Journal of Business and Management, 6(32), 153-163.

Authority, C. M. (2010). A comparative analysis of the performance of African stock markets for the period 2008-2009. Research, Policy Analysis and Planning Department Working Paper.

Awa, H. O., Ojiabo, O. U., \& Emecheta, B. C. (2012). Integrating TAM and TOE frameworks and expanding their characteristic constructs for e-commerce adoption by SMEs. Proceedings of Informing Science \& IT Education Conference (InSITE 2012).

Bagorogoza, J., \& de Waal, A. (2010). The role of knowledge management in creating and sustaining high performance organisations: The case of financial institutions in Uganda. World Journal of Entrepreneurship, Management and Sustainable Development. 6 (4).

Garrigós-Simón, F. J., \& Marqués, D. P. (2004). Competitive strategies and firm performance. Management Research: Journal of the Iberoamerican Academy of Management. 2 (3). 
INTERNATIONAL JOURNAL OF ACADEMIC RESEARCH IN BUSINESS AND SOCIAL SCIENCES Vol. 10, No. 10, 2020, E-ISSN: 2222-6990 @ 2020 HRMARS

Che Zuriana, M. J., \& Rapiah, M. (2011). Performance Measurement System (PMS) In Small Medium Enterprises (SMES): A Practical Modified Framework. World Journal of Social Sciences. 1(3), 200-212.

Cheing, A., Hong, E. H., Kuek, T. Y., Chai, B. H. B., \& Cham, T. H. (2020). Social Media Effectiveness Indicators of Microenterprise Strategic Planning. Asian Journal of Business Research, 10(1), 150.

Chong, H. G. (2008). Measuring performance of small-and-medium sized enterprises: the grounded theory approach. Journal of Business and Public Affairs, 2(1), 1- 10.

Christopher, D. I., \& David, F. L. (2003). Coming Up Short on Nonfinancial Performance Measurement. Retrieved 20 $20^{\text {th }}$ July 2019: https://hbr.org/2003/11/coming-up-short-on-nonfinancialperformance-measurement

Daniel, K. K., \& Okibo, W. B. (2014). Competitive Strategies and the Non Financial Performance of Micro-enterprises in Kenya (A Survey of Industrial Knitting Micro-enterprises in Kiambu County). International Journal of Management and Commerce Innovations, 2(2), 160186.

European Commission. (2015). Annual Report on European SMEs 2014/2015. Retrieved 20 July 2019: https://www.google.com/url=http\%3A\%2F\%2Fec.europa.eu\%2FDocsRoo

Farhan, S. F., \& Nur Naha A. M. (2011). The Critical Success Factors of Performance Measurement for Malaysian SME's in Manufacturing Sectors: A Proposed Framework.

Proceeding of $2^{\text {nd }}$ International Conference on Business and Economic Research (ICBER 2011).

Khrystyna K., Melina L. M., \& Rita R. (2010). Micro, Small, and Medium Enterprises around the World: How many are there, and what affects the count? Retrieved 31 July 2019:

http://www.ifc.org./wps/wcm/connect/MSME-ClAnalysisNote.pdf

Kotane, I., \& Kuzmina-Merlino, I. (2017). Analysis of small and medium sized enterprises' business performance evaluation practice at transportation and storage services sector in Latvia. Procedia Engineering, 178, 182-191.

Krishna, M., Annie T., Caroline C., Chang, S. W., Jonathan T. Y. P. \& Tan. K. L. (2012). A Study on Factors Affecting the Performance of SMEs in Malaysia. International Journal of Academic Research in Business and Social Sciences, 2(4), 224-239.

Mamorena, L. M. \& Olumide, H. B. (2014). Nonfinancial Performance Measures in Small Medium Enterprises' Supply Chain Management. Economics Journal, 5(3), 247-257.

Mbugua, S. K., Agnes, N., \& Ondabu, I. T. (2014). Factors Affecting the Performance ofSmall and Micro-enterprises in Limuru Town Market of Kiambu Country, Kenya. International Journal of Science and Research Publications, 4(12), 2250-3153.

Monge-Gonzalez, R., \& Torres-Carballo, F. (2015). The Dynamics of Entrepreneurship in Costa Rica. An Analysis of Firm Entry, Exit, and Growth Rates. Inter-American Development Bank Discussion Paper.

Hazlina, N. A., \& Pi-shen, S. (2009). Dissecting behaviours associated with business failure: A qualitative study of SME owners in Malaysia and Australia. Asian Social Science, 5(9), 98-104.

Nurazree, M., \& Mohd Faiz, H. (2013). TQM and Malaysian SMEs Performance: The Mediating Roles of Organization Learning. Procedia-Social and Behavioral Science, 130, 216-225. 
INTERNATIONAL JOURNAL OF ACADEMIC RESEARCH IN BUSINESS AND SOCIAL SCIENCES

Vol. 10, No. 10, 2020, E-ISSN: 2222-6990 @ 2020 HRMARS

Nurulhasanah, A. R., Zulnaidi, Y., \& Rafisah, M. R. (2014). Determinants of successful financial management among micro entrepreneur in Malaysia. Journal of Asian Scientific

Research,4(11), 631-639.

Nyanga, T., Zirima, H., Mupani, H., Chifamba, E., \& Mashavira, N. (2012). Survival of the

Vulnerable: Strategies Employed by Small to Medium Enterprises in Zimbabwe to

Survive an Economic Crisi'. Journal of Sustainable Development in Africa, 15(6), 142-152.

Nyangoma, P. S. (2012). Credit Terms, Access to Finance and Financial Performance of SMEs in Kampala. Unpublished Master thesis, Makarere University.

Peninnah, M. M. (2014). An Investigation into the Factors Influencing Sustainability of Women Owned SMEs in Kenya: A Case of Machakos Country. Unpublished Master thesis, University Of Nairobi.

Rosli, M. M., \& Sidek, S. (2013). The Impact of Innovation on the Performance of Small and Medium Manufacturing Enterprises:: Evidence from Malaysia. Journal of Innovation Management in Small \& Medium Enterprises, 2013, 1.

SME Corp. (2014). SMEs Annual Report 2014/2015. Retrieved 30 December 2019: http://www.smecorp.gov.my/index.php/en/resources/2015-12-21-11-07-06/smeannual report/book/7-annual-report-2014/2-annual-report

Souksavanh, V. (2014). Entrepreneurship, Government Policy and Performance of $\quad$ SMEs in Laos. GSICS Working Paper Series, Kobe University.

Tayeh, M., Al-Jarrah, I. M., \& Tarhini, A. (2015). Accounting vs. market-based measures of firm performance related to information technology investments. International Review of Social Sciences and Humanities, 9(1), 129-145.

Tundui, C. S., \& Tundui, H. (2012). Survival, Growth Strategies and Performance of Women Owned Micro and Small Businesses in Tanzania. International Journal of Business and Management, 7(8), 143-155.

The World SME Forum (WSF). (2015). A Business Plan for SME Advancement Globally.

Wong, K. L., Kuek, T. Y. \& Ong, S. F. (2013). Strategic Planning and Business Performance: A Study of SMEs in Malaysia. Proceedings of $3^{\text {rd }}$ Asia-Pacific Business Research Conference (APBRC 2103).

Wu, D. (2009). Measuring Performance in Small and Medium Enterprises in the Information \& Communication Technology Industries. Unpublished Doctorate of Philosophy thesis, Royal Melbourne Institute of Technology (RMIT) University. 